Article

\title{
Teacher Education and Sustainable Development Goals: A Case Study with Future Biology Teachers in an Angolan Higher Education Institution
}

\author{
António Valter Chisingui ${ }^{1}(\mathbb{D})$ and Nilza Costa ${ }^{2, *(1)}$ \\ 1 Department of Natural Sciences, Higher Institute of Education Sciences (ISCED-HUÍLA), \\ Sarmento Rodrigues St., 230 Lubango, Angola; valter.chissingui@isced-huila.ed.ao \\ 2 Research Centre on Didactics and Technology in the Education of Trainers (CIDTFF), University of Aveiro, \\ 3810-193 Aveiro, Portugal \\ * Correspondence: nilzacosta@ua.pt
}

Received: 2 April 2020; Accepted: 13 April 2020; Published: 20 April 2020

check for updates

\begin{abstract}
National education policies are increasingly regulated by international agendas, for example the Agenda 2030 for Sustainable Development (SD). However, in order to put such policies into practice, social actors like teachers and teacher educators must include them in their practices. In this context, this study stems from the following research question: how does initial teacher education (ITE) promote the SD Agendas (2030 and 2063 for Africa)? The approach to this question is carried out through a case study focused on an Angolan teacher education higher education institution, in its graduate course for future secondary school biology teachers. The main aims of this study are (i) to characterize how ITE includes SD and (ii) to suggest ways to improve SD, particularly focusing on students' future professional needs. Data were gathered from document analysis (the pedagogical curriculum plan of the course; titles and abstracts of final-year future biology teachers' essays) and an interview with the course director of the biology teaching program of the Angolan institution. Content analysis of the gathered evidence was based on a three-dimensional framework: (a) SD goals (SDG) and the curriculum; (b) teacher education principles; and (c) current Angolan curricular perspectives. Results show that although the Pedagogical curriculum plan and the formative path, from the interviewee's point of view, do not explicitly integrate SDG and its challenges for biology ITE, the majority of essays analyzed are locally contextualized and in a number of cases articulated with some of the 17 SDG. Suggestions for inclusion of SDG in ITE and for teacher education research are put forward.
\end{abstract}

Keywords: sustainable development; biology; initial teacher education; Angola; case study

\section{Introduction}

Nowadays it is difficult to question the need to "save the planet" we live in, and for this to occur one must think and act towards a more sustainable world. Despite the efforts which have been put forth by politicians and leaders of many countries around the world, for example by signing the Agenda 2030 [1,2], which establishes the 17 goals for sustainable development (SD), such efforts will not be successful without the commitment of all citizens. Considering that education has a crucial role in active and critical citizens' development, schools and teachers must be prepared to integrate in their actions the importance of the SD agenda. Therefore, teacher education (TE), and initial teacher education (ITE) must include in their formative paths the preparation of (future) teachers to deal with such challenges. This means that TE and ITE must take explicit strategies on board to promote the development of professionals with competences that educate responsible citizens, namely as far as SD is concerned. 
If the above is necessary in developed countries, it is even more relevant in developing countries like Angola, where societal and environmental problems are seriously present [3]. Notice that the need and adaptation of SD in African countries made their leaders sign the Agenda 2063, "Africa for all" [4]. In this sense, and considering teachers' knowledge, skills and attitudes about and towards SD-an important dimension for their job—this paper also addresses the effort of empowering Angolan teachers' employability [5,6]. In fact, while access to employment has not been a problem in Angola due to the current expansion of the educational system, the supply of qualified teachers remains a national challenge [7].

The arguments put forward justify the main goal of this study: to understand how ITE takes on board the preparation of future teachers to promote pupils' and students' commitment towards SD. This understanding will sustain recommendations towards SD in ITE. In order to achieve this goal, and given the academic and professional profile of the authors of this study, a case study was developed in the context of an Angolan higher institution of ITE, with future biology teachers. The first author of this article is a professor and a researcher at the Angolan institution where the study was developed. In addition, he has held the position of vice-director, for 4 years, for the scientific area. The second author has been collaborating with this Angolan institution for about 10 years, in particular in the area of postgraduate teacher education. Document analysis of the biology ITE pedagogical curriculum plan and final-year essays written by future teachers, as well as an interview with the coordinator of the biology education program, were the techniques used to collect data. Content analysis was the method applied to the data.

The structure of the article includes, apart from this introduction, the following sections: a literature review in order to establish the framework of the study; the presentation of the methodology used; the main results of the study and their interpretation; and final recommendations for ITE and research. Apart from the references listed at the end of the article, we include two annexes (annex 1 with the titles of the 21 essays analyzed, and annex 2 with the results of the analysis of each student essay).

\section{Research Framework}

This section presents first a brief overview of the state-of-the-art of the scientific research in Angola in general, and in educational research, TE and ITE in particular. This supports both the need to develop research in the country and the scarce inclusion of national scientific references in the theoretical framework (ThF) of this study. Then, the ThF is presented, including three dimensions, concerning: (a) the concepts of sustainable development (SD) and sustainable development goals (SDG) and their implications for education and educational school curricula; (b) guidelines for TE and ITE in general, and in particular with respect to biology ITE, which aims to introduce SDG into teaching practices in order to contribute to better prepared professionals; and (c) guidelines underlying the actual secondary education curricular reform in Angola.

\subsection{The Need to Develop Research in ITE in Angola}

Educational scientific research in Africa, and in Angola in particular, is still an underdeveloped domain [8]. More specifically, teacher education, ITE and biology ITE research are almost non-existent in Angola when compared with other domains. To illustrate such a difference, Table 1 shows the results of a database Google Scholar search, performed on 5th December 2019 by the authors. The results were obtained by searching references in the Portuguese language, since 2015, about TE, biology TE, ITE, and biology ITE studies carried out in Angola and Portugal, the countries of the authors of this study. Despite the obvious differences between the two countries (for example in terms of population (while Angola has a current population of $32,597,073$ citizens, representing $0.42 \%$ of the world population, Portugal has a current population of $10,203,936$ citizens, representing $0.13 \%$ of the world population. Please consult https://www.worldometers.info/world-population/) and citizens enrolled in a tertiary education (in Angola only 9\% of the population is enrolled in a tertiary education and may potentially have the possibility to conduct research in educational contexts, while in Portugal $63 \%$ of the population 
is enrolled in tertiary education. Please consult http://hdr.undp.org/en/indicators/63406), the results presented give an idea of the need to develop research in the context of the study of this article.

Table 1. Results of Google Scholar references in the field of teacher education in Angola and Portugal since 2015.

\begin{tabular}{ccc}
\hline Scholar Google References & $\begin{array}{c}\text { Conducted in the Angolan } \\
\text { Context }\end{array}$ & $\begin{array}{c}\text { Conducted in the Portuguese } \\
\text { Context }\end{array}$ \\
\hline Teacher Education (TE) & 10,500 & 24,300 \\
Biology TE & 1860 & 15,600 \\
Initial Teacher Education (ITE) & 7570 & 17,800 \\
Biology ITE & 1410 & 14,000 \\
\hline \multicolumn{2}{c}{ Note: Search conducted in 12th December 2019. }
\end{tabular}

Note: Search conducted in 12th December 2019.

\subsection{Sustainable Development, Sustainable Development Goals and Their Implications for Education and Educational School Curricula}

The era of globalization has repercussions in the political, economic and social spheres worldwide, and also, and most significantly, in education [7]. The existence of national educational policies devoid of influence from international agendas is difficult or even impossible today. As stated by [9]: "Thirty years ago, education within national borders has been the subject of increasing international influence" (p. 940). One of the influences with the most recent impact is the UNESCO Agenda 2030, approved on the 25th of September 2015, which resulted from the work of governments and citizens around the world [1,2]. Its main purpose is to contribute, globally and by 2030, to the eradication of poverty and gender inequalities, the reduction of inequalities within and between countries, the protection of the environment and the fighting against climate change, thereby promoting the prosperity and well-being of all.

This Agenda integrates 17 SDG to be implemented by all countries, namely: No poverty (1st); Zero hunger (2nd); Good health and well-being (3rd); Quality education (4th); Gender equality (5th); Clean water and sanitation (6th); Affordable and clean energy (7th); Decent work and economic growth (8th); Industry, innovation and infrastructures (9th); Reduced inequalities (10th); Sustainable cities and communities (11th); Responsible consumption and production (12th); Climate action (13th); Life below water (14th); Life on land (15th); Peace, justice and strong institutions (16th); and Partnerships for the goals (17th).

It should be noted, however, that the concept of SD was already a central concern, namely put forth by the UN World Commission on Environment and Development, in 1987, and clearly reflected in the Brundtland Report "Our Common Future" [10]. Among the 17 SDG there is one that is specific for education - the 4th SDG. This aims to "Ensure inclusive and equitable quality education and promote lifelong learning opportunities for all". Thus, as this label suggests, quality education is sought at a global level (in which education systems certainly play a key role), in promoting inclusion, equity, and the promotion of lifelong learning opportunities. However, and as referred by [11], “ ( ... ) education is important to all 17 goals ( . . ) because sustainability in essence poses an educational challenge for humankind ( ... )" (p. 51). The same author highlights the importance of integrating into the 21st century education scenario the education for sustainable development (ESD), which seeks to prepare learners and future employees with competences to deal with the world global challenges (environmental, social and economic).

The concept of SD, which is central to this article, will now be explored a little further. First, and as a curiosity, it can be noticed that some authors claim, according to [10] (p. 1), that the SD designation was based on the popular African saying "We do not inherit the Earth from our Parents we borrow it from our Children". The concern with the "Earth", "intergenerational inheritance" and their connection, is clearly at the root of the development concept and of its relevance, presented in the aforementioned Brundtland report. It has merged in deep and wide-ranging analyses of the 
unsustainable situation of the present world, as a consequence of human activities that have generated (and unfortunately continue to generate in many parts of the world) serious glocal socio-environmental problems (e.g., climate change, biodiversity loss), and the urgent need to find (joint) solutions towards a transition to a sustainable world.

We will use here the definition of SD offered by the UN Commission for Sustainable Development of 1988, which states that [12] (p. 1) "Sustainable Development is one that meets the needs of the present without compromising the ability of future generations to meet their own needs".

Notice that if globalization looks for a global thinking it also points to a local one. Hence one adopts the designation "glocal" due to the relevance that we intend to give, in the sphere of education, to the idea that educational actors (teachers, students ... ), nowadays, must "think globally and act locally" - a phrase presented for the first time by Frank Feather, the Canadian President of Global Marketing, in 1979 (For more information please see http://www.historiadaadministracao.com.br/jl/gurus/59-frank-feather and http://keynotespeakerscanada.ca/speaker/frank-feather-0).

The concept of "glocal" is understood by us according to the definition given by [13], who argue that "glocal":

“ ( ... ) captures the importance of integrating both local and global considerations when addressing the pressing real-world sustainability problems of our time. (...) A glocal teaching-learning environment organizes spaces, places, and people so as to allow students to learn how to address real-world sustainability problems in local and global contexts". (p. 31)

Several studies [11], including in the Angolan context [14,15], mention the importance of addressing SD in the curriculum, from kindergarten to higher education. As referred by Bell, "Sustainability will be embedded into educational content. This will help encourage a change in the way people understand their social, technological, ecological and political environments" (p. 53).

\subsection{Orientations for (I)TE, SD and Biology ITE}

According to [16,17], who conducted a study in a public higher education institution located in Lubango (Angola), one fundamental condition for glocalization through education is to have highly qualified teachers. Notice that this corroborates the need stated in the Agenda 2030 [2], namely to "Review, analyze and improve the quality of teacher training (pre-service and in-service) and provide all teachers with quality pre-service education and continuous professional development" (p. 24). But what suggestions emerge from the literature for such an endeavor? y A key issue when one thinks about TE is to give meaning to what is peculiar to the teaching profession and therefore what distinguishes it from other ones. According to [18] and going back to the Schulman model, it is the pedagogical content knowledge (PCK) which is "a specific form of knowledge for teaching related to the transformation of particular content in the context of enhancing student learning".

As to ITE, [19] proposes a "Practicum Model", which is a model that looks for (future) teacher professional development in which teaching practice is seen as " $(.$.$) a space of transformation rather$ than a process of adaptation or of application of theory ( ... )" (p. 621). Only by experiencing this space of transformation can the (future) teacher overcome "traditional" education principles, in which the teacher transmits knowledge to the students. This should be changed to a "transformational" education scenario in which "the teacher facilitates the acquisition of skills and competences in addition to essential values and knowledge" [11] (p. 52).

However, this must be seen today, as many authors refer [20-22], within a scope where (future) teachers acquire competences to promote critical and glocal citizenship to act towards supporting a sustainable planet. But what are those competences and how do we promote them in TE, and particularly in ITE?

Cebrián and Junyent [23] developed a framework of professional competences in education for SD which, among others, should include the following components: contextualizing, which means 
to take on board the spatial (local-global) and the temporal dimensions (past, present and future) of a given problem or situation; work and live with complexity, that is the ability to connect several dimensions of a problem (economic, environmental, and social) in the school context; decision-making, participation and acting for change, expressing not only awareness but moving to action, sharing responsibilities and engaging in joint actions. The same authors, aiming to explore conceptions of student teachers in relation to education for SD competences, conclude that future teachers tend to value the natural environment, instead of a more integrated vision that includes other dimensions (e.g., social and economic). Therefore, there is a need to (re)think TE from that perspective. Bourn, Hunt and Bamber [24] propose the following lines to be introduced in ITE for SD: educating through (a) emphasizing the purpose and role of teaching and its wider social role; (b) subjects/contents like citizenship/civics/social studies; (c) compulsory courses (not only optional); and (d) debates with a broader social purpose of education (e.g., gender equality, peace education and human rights).

As far as biology ITE and sustainable development are concerned, a recent article [25] argues that (future) biology teachers, having biology and education expertise, can have an important role in solving (future) problems and therefore achieve the 17 SDG, especially in developing countries. For this to occur, " (.. ) biology science and education must be comprehensive and including everything in the world and powerful to solve the problems emerged to support SDGs" (p. 287). As far as biology science and education knowledge are concerned, and as referred by the same authors, its role to deal with and solve social and environmental problems should be noticed.

\subsection{Guidelines Underlying the Actual Curricular Reform for Secondary Education in Angola}

Finally, focusing on guidelines underlying the actual secondary education curricular reform in Angola, it is important to refer to the following recent study by Afonso [26] (The current Director of the National Institute for Educational Research and Development (INIDE)), where he reflects upon the educational reality in Angola through the curricular changes that have occurred in primary and secondary education in the last thirty years. The author states the urgent need for a pedagogical paradigm transformation, as those changes have not overcome the expectations of society regarding education quality. This paradigm shift is based on two key ideas: the integration between universal and local knowledge; and the curricular development sustained in the achievement of CHAVE (the Portuguese acronym (In Angola the official language is Portuguese. Angola has also 20 national languages (for more information please consult http://www.fao.org/tc/cplpunccd/paginas-nacionais/ angola/en/)) for "Conhecimento/knowledge, habilidades/skills, Atitudes/attitudes, Valores/values and Ética/ethics), which, as a word, means "key" and is considered to be the "key" solution towards more empowered Angolan citizens. Therefore, CHAVE integrates not only cognitive dimensions, but also psychomotor, affective and axiological ones. However, and as the author emphasizes, the educational reality in the country is still focused on the " $\mathrm{C}$ " (knowledge) dimension, or, from a limited scope, on "CHA" (knowledge and skills), and therefore still lacks the "VE" (values and ethics) components. In order to change this situation, the National Institute for Educational Research and Development (INIDE) is carrying out a curricular review process that began in 2018 and will end in 2025 [27]. This curriculum review underlies the need to invest in teacher education, pre/in-service and post-graduation in the country, still due to their poor education $[16,17]$.

Aligned with the CHAVE perspective, Lunga [28] carried out a study in Angola about the need to develop environmental education within the curricula, recognizing the relevance to develop in the students not only knowledge (to understand the environment and its problems), but also abilities (to develop skills needed to solve environmental problems), attitudes (to acquire social values towards the environment and willingness to actively participate in its improvement and protection), and values (to be aware of the importance of preserving the environment, namely to prevent diseases).

In summary, one can say that TE and ITE in general, and for (future) biology teachers in particular, may play an important role in developing citizens with the knowledge and behavior to act towards and within the SD Agenda. For this to occur, TE programs need to make educational aims, contents 
and strategies towards teachers' SD actions explicit. For example, to make (future) teachers aware of the 4th SD goal as well as how education can influence the achievement of other SDG, and to frame glocally their content pedagogical knowledge. As far as biology science and educational knowledge are concerned, and as referred by [25], its role in dealing with and solving social and environmental problems should be noticed. Additionally, and in order to make (future) teachers work in an up-to-date educational paradigm, teacher training strategies should be based on "transformational" education in which teacher educators facilitate the acquisition of competences "in addition to essential values and knowledge" [9] (p. 52). Finally, the actual curriculum reform under development in Angola emphasizes the need to approach school curriculums in a way that enables students to develop not only knowledge but also abilities, attitudes, values and ethics, and that is what CHAVE is about.

\section{Methodology}

The methodology of the developed study followed a case study approach. According to Yin [29], the case study may be used in order to describe and interpret a contemporary complex phenomenon within its context. It looks for a deep understanding of a single and well-defined situation and its "how" and "whys". Its description and understanding are attained through a variety of sources of evidence. Case study results cannot be statistically generalized but instead the generalization is for theory and similar situations [30]. In the study described in this paper, the research context is an Angolan teacher education institution, and the case consists of how ITE for future biology teachers is developed, namely as far as SD is concerned. Table 2 summarizes the methods and instruments used to collect data, and the specific research questions addressed by each one. Content analysis was applied to the data collected according to Bardin [31].

Table 2. Methods and instruments used to collect data and their respective specific research (questions).

\begin{tabular}{|c|c|}
\hline Methods and Instruments & Research Questions \\
\hline $\begin{array}{l}\text { Documental analysis of the pedagogical } \\
\text { curricular plan (PCP) of the higher } \\
\text { education institution (last update 2016) }\end{array}$ & $\begin{array}{l}\text { What kind of aims, subjects and strategies are contemplated in the } \\
\text { PCP, and particularly as far as the essay students should do at the } \\
\text { end of the course are concerned? } \\
\text { To what extent does the PCP include orientations concerning the } \\
\text { DS agenda? }\end{array}$ \\
\hline $\begin{array}{l}\text { Interview with the coordinator of the } \\
\text { "Biology Teaching" program }\end{array}$ & $\begin{array}{l}\text { What are the academic, pedagogical and professional orientations } \\
\text { the coordinator considers to be present in the biology teaching } \\
\text { program? Are those orientations discussed with the teachers? } \\
\text { How is the final subject of the program (essay) organized? } \\
\text { To what extent does the curriculum include dimensions presented } \\
\text { in the actual curricular reform of the country, which may promote } \\
\text { professionals that include SDG in their practices? }\end{array}$ \\
\hline $\begin{array}{l}\text { Document analysis of final-year (5th year) } \\
\text { "Biology Teaching" students' essays } \\
\text { (titles and abstracts) - } 2018 \text { academic year }\end{array}$ & $\begin{array}{c}\text { What kind of topics, aims and glocal scenarios are presented in } \\
\text { students' essays? } \\
\text { To what extent do the essays include orientations } \\
\text { concerning SDG? }\end{array}$ \\
\hline
\end{tabular}

\subsection{The Context of the Case Study}

The institution where our study was developed is located in the Huilla Province of Angola (see Figure 1). It is a public higher educational sciences institution (with the acronym ISCED) dedicated to teacher education in different fields (e.g., languages, sciences, sports). The institution was created in the 1980s, and it is seen as a prestigious institution of the country. Besides ITE programs, the institution also offers master's degrees, namely in science teaching/biology. At present it offers 13 undergraduate degree programs in initial teacher education and four master's degree programs, and has around 7000 students. 


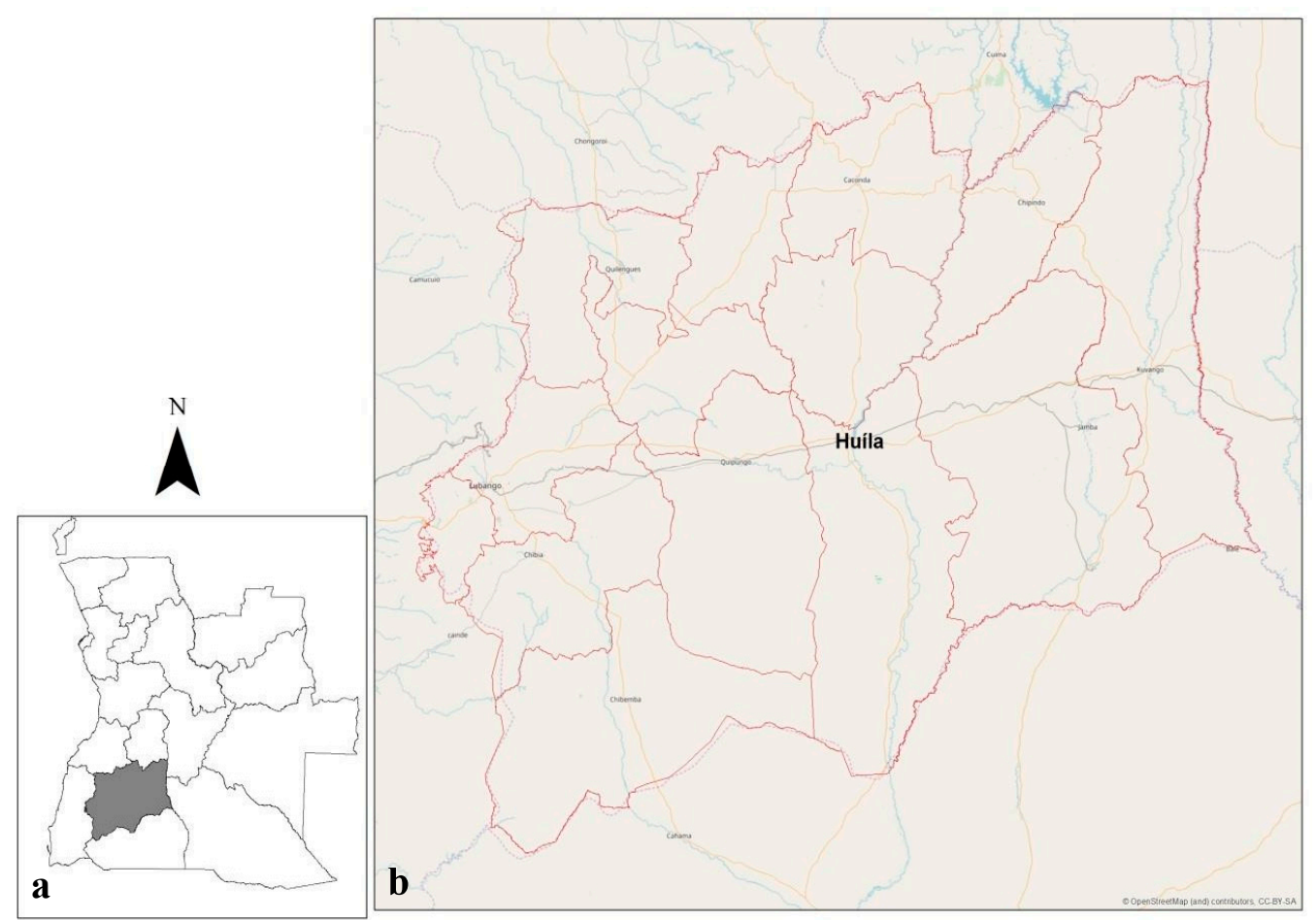

Figure 1. (a) Huíla Province in Angola (in grey); (b) map of Huila Province (Sources: Esri, HERE, Garmin, USGS, Intermap).

Notice that in Angola there is one public higher education institute of educational sciences in each of the 18 provinces of the country. ISCED are therefore seen as provincial institutions, and although they have a certain degree of autonomy, they are directly bound to the ministry of higher education.

ISCED are the Angolan institutions that have as their main mission to educate teachers through undergraduate and master degree programs for secondary education. The first ISCED created in the country is the one where our study was developed.

\subsection{Data Analysis}

Given the qualitative research dimension of our empirical study, our first concern fell on what kind of validity framework should be used in our data analysis. The answer to this was found in [30], where the authors present a "validation-as-iterative-interactive-process" framework, which, instead of considering a "single validity test", proposed a "set of strategies and continuous procedures", such as: "context-based validation", "theory-based validation", "response validation", "criterion-related validation", and "consequential validation". Given the novelty and complexity of qualitative research, when compared with quantitative research, the authors consider that the validity of a knowledge claim "is a function of the context of use and the inter-subjective judgment" (p. 18).

According to that, and given the design of the research approach, which involves dialogic cooperation between two scholars with different backgrounds, namely Portuguese and Angolan [32,33], as well as the qualitative nature of our data, several strategies were used for data analysis: triangulation of results emerged from the content analysis of the pedagogical curricular plan of the course and the interview transcription; validation of the researchers' transcriptions by the interviewees; and the co-development of an instrument of analysis (IA) for the students' essays by the two authors of the research. With respect to this, and as will be described next, the IA emerged from our theoretical framework ("theory-based validation"). Additionally, the criteria used to set the dimensions of the IA were clearly defined ("criterion-related validation"). To claim the inter-subjective judgments of the results, two strategies were used: first, each of the authors applied the IA separately to all of the data, and only afterwards the results were confronted and negotiated; second, and aiming at transparency, 
all the titles of the essays are given (see annex 1), and the indicators selected are presented for each student essay analysis (see annex 2) — criterion-related validation.

\subsection{The Analysis of the Pedagogical Curricular Plan (PCP) and the Interview Transcript}

The specific research questions presented in Table 2 guided the analysis performed, both in the PCP and in the interview transcription after validation by the interviewee. The main results presented in Section 4 concerning these two data sets will be illustrated with quotations from the PCP and the interview transcription.

\subsection{The Instrument of Analysis of the Essays}

Based on our theoretical framework (ThF) summarized above, an instrument of analysis (IA) was developed (see Table 3) to guide the description and interpretation of the 21 essays (title and abstract) of the 2018 academic year. Notice that those 21 essays correspond to $83 \%$ of the total essays produced in that particular school year. However, due to difficulties in accessing information in the institution, it was not possible to collect all of the essays. This difficulty converges with the commonly referred problem of the lack of African institutional practices to systemize and monitor documents $[7,17]$. Therefore, the development of this research study per se functioned as a primer for institutional development by reinforcing the importance of maintaining an open database of the research produced by home students.

The IA has four dimensions: the first is about PCK, that is, if the information analyzed in each essay includes biology knowledge transposed to the school setting; the second concerns the contextualization of the study, that is, if the study arises from a problem (e.g., environmental or social); the third is related to CHAVE, that is, if the study aims to look for students'/teachers' development of knowledge, abilities, attitude, values and ethics; and the fourth is SDG, that is, if there is an articulation, even if not explicitly, between the topic studied and any of those goals (the 4th SDG and/or others). For example, if topics are related to social and environmental glocal scenarios-3rd or 5th SDG; if it includes partnerships among educational actors, like (future) teachers, and other entities, like the communities-17th SDG).

Table 3. Dimensions and brief descriptions of the instrument of analysis.

\begin{tabular}{|c|c|}
\hline IA Dimension & $\begin{array}{c}\text { Brief Description (Key Words; Aim(s); Topic } \\
\text { Contextualization) }\end{array}$ \\
\hline & The essay (title and abstract) includes ... \\
\hline D1-Pedagogical content knowledge (PCK) & ... biology knowledge transposed to the school context \\
\hline D2-Contextualization & $\begin{array}{l}\text {... a contextualized situation at a global, local and glocal } \\
\text { dimension }\end{array}$ \\
\hline D3-CHAVE development & $\begin{array}{c}\ldots \text { (future) teachers' and/or students' development of } \\
\text { knowledge, abilities, attitudes, values and ethics }\end{array}$ \\
\hline D4-Articulations with the SDG Agenda 2030 & ... dimensions which may be linked with one or more SDG \\
\hline
\end{tabular}

Table 4 presents the instrument of analysis (IA), which was filled with the data collected from each of the students' essays (title and abstract). In articulation with Table 3, the IA includes: the code of each student' essay (St1; St2 ... St21); indicators emerged from each essay; a 4-level scale for all dimensions, except for dimension 1 , which only has three values as there was no conceptual argument for a 4th value to be added. The indicators are the results of the analysis performed in terms of emerged keywords, the aim(s) of the study and its glocal context. The keywords integrate the main concepts and were defined by the researchers taking into account the main elements of the title and abstract of each essay analyzed. The criteria used to attribute the scale value for each dimension are presented in Table 5. The IA also includes final observations about dimension 4 (D4), and this is the SDG that may be associated with the essay. As previously mentioned, the analysis of each student's essay was 
analyzed separately by each author of the article, and only afterwards the outcomes were negotiated to reach a shared consensual result.

Table 4. The IA of the students' essays (title and abstracts).

\begin{tabular}{|c|c|c|c|c|c|}
\hline \multirow[b]{2}{*}{ IA Dimension } & \multirow{2}{*}{$\begin{array}{l}\text { Indicators } \\
\text { Key Words that Emerge from the } \\
\text { Content Analyses of the Titles and } \\
\text { Abstracts of the Essays }\end{array}$} & \multicolumn{4}{|c|}{ Scale } \\
\hline & & 0 & 1 & 2 & 3 \\
\hline D1 & & & & & Not applicable \\
\hline \multicolumn{6}{|l|}{ D2 } \\
\hline \multicolumn{6}{|l|}{ D3 } \\
\hline \multicolumn{6}{|l|}{ D4 } \\
\hline Observations ab & D4: & & & & \\
\hline
\end{tabular}

Table 5. Criteria to attribute a scale value to each dimension.

\begin{tabular}{ccccc}
\hline \multirow{2}{*}{ Dimensions } & \multicolumn{4}{c}{ Scale } \\
\cline { 2 - 5 } & $\mathbf{0}$ & $\mathbf{1}$ & $\mathbf{2}$ & $\mathbf{3}$ \\
\hline D1 & No PCK & General PCK & Biology PCK & Not applicable \\
\hline D2 & No contextualization & Global & Local & Glocal \\
\hline D3 & $\begin{array}{c}\text { No component of } \\
\text { CHAVE }\end{array}$ & Only C & Only CHA & CHAVE \\
\hline D4 & No SDG & Only 4th SDG & Two SDG & More than 2 SDG \\
\hline
\end{tabular}

\section{Results}

In this section, results pertaining to the analysis of the pedagogical curricular plan (Section 4.1), the interview with the biology coordinator (Section 4.2) and content analysis of students' essays (Section 4.3) are presented.

\subsection{Documental Analysis of the Pedagogical Curricular Plan/PCP (ISCED, 2016)}

The biology teaching program, in its current version, was approved by Executive Decree no. $604 / 17$ for the higher education institute where the study was carried out. In the introduction of this executive degree it is mentioned that the institution fulfills the necessary requirements to deliver the course. The curricular plan consists of nine semesters (five years), and follows the Integrated Model of Teacher Education [20], e.g., educational courses (for example, general pedagogy) are taught from the beginning of the program, along with subjects in the specific scientific domain (general botany).

The degree in biology teaching should prepare a qualified professional to act in secondary education, that is:

“( $\ldots$ ) a professional capable of dealing with challenging situations in relation to the objectives to be achieved in schools ( ... ) a professional aware of his limitations, attentive and interested, in order to be up to date ( ... ) a critical thinker capable of systematically questioning". (PCP, ISCED; 2016, p. 12)

As for the final subject where the students must develop an essay, the pedagogical plan says that this component is:

“( ... ) a compulsory academic activity for the completion of the course. As a curricular component, it is linked with no specific subject, but it should take place in one of the curricular subareas of the biology teaching program". (PCP, ISCED, 2016, p. 20) 
This work (essay) "aims to prepare the student as a teaching practitioner, a researcher and/or somebody who works with the community, and is carried out with tutors accredited by the program scientific council". (ISCED, 2016, p. 20)

From this one can conclude that the essay could have a teaching context, but also a research or community one.

Searching in the 206 pages of the pedagogical plan of the program one did not find any words related with the Agenda 2030, 2063, SD and SDG. The absence of those dimensions can be perceived as an indicator of the lacking acknowledgement of this important relation, namely the institutional course directors. This aspect will be explored further on in the interview. Notice that those results, in articulation with political agendas, are not aligned with the ITE orientations referred to in our theoretical framework.

\subsection{Interview with the Coordinator of the "Biology Teaching" Program}

The interview with the person in charge of the course under analysis was held on the 3rd of October 2019 and transcribed and validated by the interviewee on the 11th October of the same year. The interviewee is a teacher in the institution since 1993, and is responsible for the biology teaching degree program since 2013. The interviewee refers that the main role as the person responsible for the course is to "control the academic activity" of classmates (e.g., absences). Therefore, one considers that this role is mainly administrative and not pedagogical. This is aligned with the interviewees' answer to several questions asked, for example, about whether the coordinator discusses with teachers the importance of approaching SD and SDG in the curriculum, as well as about the ongoing curricular reform in the country (CHAVE): "no, I do not discuss these issues with my colleagues, it is up to the teachers to talk about them with their students". In fact, considering dimensions related with pedagogical content knowledge answers were quite vague, in particular related to education towards sustainable development. Although the interviewee stated that he/she knows these topics "more or less".

When asked about the main aims of the study program, it was said that "The main aim is to prepare the students with the necessary quality to be able to teach biology from the 7th to the 12th grade". When asked what was meant by quality, the interviewee clarified that the quality is related to "scientific and pedagogical" expertise, but without giving further examples.

As for the organization of the final subject from which students must elaborate an essay, the coordinator said that "there are no particular orientations ( ... ) the student chooses the tutor and selects the topic to be studied with him/her. Only after that the proposal must be approved by a departmental scientific committee". When asked under what criteria those proposals are evaluated, the coordinator explained, "the topics cannot be repeated (... ) the objectives have to be well defined, as well as the population and sample".

Considering the outputs of the interview it became clear that the reflection upon pedagogical aspects related to sustainable development in the frame of initial training of biology teachers is not (yet) a common practice in the institution. Therefore, one may conclude that SD, SDG and the ongoing curricular reform are issues that are not currently approached collectively by the future teachers, and that if they are, it only depends on the motivation and activity of individual teachers. Furthermore, and with respect to the final subject, it does not seem that there are orientations apart from the criteria used to evaluate the projects. However, those criteria also do not include issues related to the relevance of the topic concerning international and national challenges.

The absence of explicit references to SD in the PCP, and in particular with respect to the orientations concerning students' essay elaboration, is in alignment with the interview outputs of the program coordinator, evidencing a higher focus on normative aspects than on pedagogical implications related to the sustainable development agenda. This signals a lack of a consolidated institutional strategy considering education of future biology teachers and sustainable development. 


\subsection{Documental Analysis of the Students' Essays}

Taking into account the content analysis of the 21 titles (see annex 1), and the results found in the IA of each student's essay abstract (see annex 2), the IA, presented in Table 4, was filled in with the data of each of the 21 essays, taking into account the criteria defined in Table 5. Table 6 presents a summary of the results of the IA filled in for each student's essay.

Table 6. Results of the 21 students' essays.

\begin{tabular}{ccccc}
\hline Dimensions & \multicolumn{3}{c}{ Scale/Level of Identification } \\
\hline & 0 & 1 & 2 & 3 \\
D1-Pedagogical content knowledge (PCK) & $8(39 \%)$ & $2(9 \%)$ & $11(52 \%)$ & n.a. \\
D2-Contextualization & $6(19 \%)$ & $0(0 \%)$ & $9(42 \%)$ & $6(19 \%)$ \\
D3-CHAVE & $3(14 \%)$ & $11(52 \%)$ & $4(20 \%)$ & $3(14 \%)$ \\
D4-Articulation with SDG2 & $0(0 \%)$ & $6(19 \%)$ & $10(48 \%)$ & $5(33 \%)$ \\
\hline
\end{tabular}

Note: n.a. means not applicable.

The summarized results indicate that the majority of the data analyzed include: (i) biology PCK (52\%); (ii) a contextualized problem (61\%), most of which refers to a local context (42\%); (iii) only the "C"/Knowledge" dimension of the "CHAVE" (52\%); and (iv) a dimension, although not explicit, which may be associated with more than one SDG (81\%).

The presence of biology PCK is understandable given that the (future) teachers are from the biology field. This can also explain the possible association with the 15th SDG. However, and despite the present Angolan curricular orientations, knowledge seems to be the most prominent dimension explored in the essays. This may be explained as due to the traditional educational scenario, centered on the transmission of knowledge, which is still very present in the Angolan educational system [18,28].

Moreover, the vast majority of the cases are associated with 4th SDG-Quality Education (90\%), but others with the 15th-Life on Land (39\%), the 3rd-Good Health and Well-Being (33\%), the 17th-Partnerships for the Goals (33\%), and finally to the 5th-Gender Equality (9\%). The possible association with the SDG, and not only with the 4th, indicates an alignment with up-to-date orientations for ITE. This interpretation of the association with SDG is because most topics approached by students emerge from a contextualized problem, although mainly local. However, the result that only $19 \%$ of the analyzed essays include both a global and local contextualization, i.e., a glocal contextualization, indicates that there is, indeed, a potential to broaden and deepen the focus of SD development by future biology teachers of this institution.

In summary, the following results are highlighted: (i) the pedagogical plan of the biology teaching degree of the institutions (ISCED; 2016) does not make any reference to the challenges posed by either the international agendas (such as the Agenda 2030 or 2063), or the national problems; (ii) the course director seems not to value them significantly, particularly in the structuring the of the final work that gives rise to the essays analyzed, leaving the responsibility of its exploration to each student individually; (iii) the students tend to choose topics that may be related to SD and SDG, but nevertheless, from a more local perspective, this is not being sustained and/or informed by the formative path. Result iii seems promising regarding the students' awareness of national and local problems from the field of biology-but not exclusively (e.g., social problems like early pregnancy), and also shows some awareness regarding the need to establish partnerships to minimize or solve these problems.

\section{Final Considerations}

This section is divided in two parts. The first presents the main results, and so gives the answers to the research question of this study, that is, "how does initial teacher education (ITE) promote the SD Agendas (2030 and 2063 for Africa)". The second presents the recommendations that emerge from the study, both for initial teacher education and research. 
Evidence provided by this research indicates that SD/SDG is not yet an issue taken into account in the pedagogical curricular program and practice of the biology ITE program of the institution where the study was carried out, at least not in a sustained an articulated way. Additionally, new national curricular orientations, like CHAVE, are not present in the program coordinator's actions. Despite that, document analysis of the titles and abstracts of the final-year students' essays shows that the future teachers tend to select topics which are related with the local environment and social problems (for example, deforestation, social inclusion due to genetic problems like albinism), which may be considered as linked with the SDG of the Agenda 2030. In addition, this tendency occurs not only with the 4th SDG-Quality Education, but also, for example, with the 15th SDG-Life on Land. A further piece of evidence is the fact that students often involve community actors in their studies, which may be linked with what the 17th SDG proposes-Partnerships for the goals. The results that emerged from the students essays' analysis are seen as promising, even if the study cannot discuss its impact on the future teachers' practices. This last result is promising in the sense that future biology teachers who were involved in the study appear to be at least internally motivated to explore issues related to the SD Agenda (2030 and 2063).

In order to give impact to the study, one recommends:

- $\quad$ For policymakers, the need to rethink ITE so as to promote professionals who can contribute towards a more sustainable world. In particular, by making explicit in the ITE programs the relevance of SD challenges, not only in biology ITE but also in all other disciplinary subjects. Additionally, the need to invest in the formation of teachers educators, particularly course directors, in order to look for an alignment between policies and institutional practices.

- For teachers education institutions, and namely for the one where the study was carried out: as the study constitutes a first step towards the awareness of teachers educators of the analyzed institution, one recommends the need (i) for its discussion inside the institution; (ii) to revise and integrate the SD goals, targets and indicative strategies in the PCP; and (iii) to implement and monitor this revision in the institution practices.

In summary, and in accordance with Darling-Hammond [34], and despite the growing scientific knowledge regarding teaching and teacher education, this knowledge has frequently been ignored, misinterpreted, or misused-sometimes by teacher educators and more often by policymakers. Therefore, one recommends that this research is taken on board by educational policymakers, namely in Angola, for example in needed reforms in ITE and in the accountably processes, evaluation and accreditation of ITE programs as suggested by Bourn, Hunt and Bamber [24].

As far as research is concerned one recommends to pursue with (a) similar studies in other institutions and ITE programs in order to guide curricular reforms in ITE, and (b) follow up studies with future biology teachers involved in our research in order to analyze the impact of this training orientation on their practices. These studies may offer contributions on how SD can be introduced in practices, as well as to understand how ITE could be designed to enhance this impact.

As referred, teachers can have an important role in the education towards a more sustainable world, but for this to happen teacher education institutions and teacher educators should explicitly integrate SD aims, contents and strategies in their programs. Even though, given the methodology approach of this study, its results cannot be statistically generalized, it may happen that future teachers, particularly in the field of biology, and in contexts where there are serious environmental and social problems, are already open to such curricular changes and educational goals.

This paper ends with a quotation from Bourn, Hunt and Bamber [24] in order to emphasize one key idea of this research:

"A priority in all countries must be to encourage all bodies responsible for providing teacher education to support all teachers to be aware of the social, cultural and environmental relevance and impact of what they teach, and to encourage a sense of global and environmental responsibility and a belief in social justice". (p. 29) 
Author Contributions: Conceptualization, A.V.C. and N.C.; methodology, N.C. and A.V.C.; analysis, N.C. and A.V.C.; writing, A.V.C. and N.C. All authors have read and agreed to the published version of the manuscript.

Funding: This work is financially supported by National Funds through FCT-Fundação para a Ciência e a Tecnologia, I.P. under the project UIDB/00194/2020, associated to CIDTFF and ISCED. The funders had no role in the design of the study; in the collection, analyses, or interpretation of data; in the writing of the manuscript, or in the decision to publish the results.

Acknowledgments: The authors acknowledge all informants involved in the study, as well as the administrative and technical support of the hosting institutions of the researchers.

Conflicts of Interest: The authors declare no conflict of interest.

\section{References}

1. United Nations General Assembly. Transforming Our World: The 2030 Agenda for Sustainable Development; Resolution 70/1; Document A/RES/70/1; United Nations General Assembly: New York, NY, USA, 2015.

2. UNESCO. Education 2030: Incheon Declaration and Framework for Action towards Inclusive and Equitable Quality Education and Lifelong Learning for All; UNESCO: Paris, France, 2016.

3. UNICEF. Angola Formative Evaluation Report (Consultancy Services for the Formative Evaluation of UNICEF Angola Country Programme (2015-2019) UNICEF). 2018. Available online: https://www.unicef.org/ evaldatabase/files/Angola_CP_Formative_Evaluation_Report_Final_Report.pdf (accessed on 18 November 2019).

4. African Union Commission (AUC). Agenda 2065-The Africa We Want; AUC: Addis Ababa, Ethiopia, 2015.

5. Tynjälä, P. Toward a 3-P Model of Workplace Learning: A Literature Review. Vocat. Learn. 2013, 6, 11-36. [CrossRef]

6. Paiva Dias, G.; Melo, A.I.; Lopes, B.; Seabra, D.; Brito, E.; Costa, M.; Silva, P. Os Estágios Curriculares e o seu Impacto na Empregabilidade dos Licenciados [Curricular Internships and Its Impact on Graduates Employability]; UA Editora: Aveiro, Portugal, 2015; ISBN 978-972-789-443-7.

7. Breganha, G.; Lopes, B.; Costa, N. Using students' voice towards quality improvement of Angolan secondary physic classes. Probl. Educ. 21st Century 2018, 76, 289-298. Available online: http://oaji.net/articles/2017/4571529089411.pdf (accessed on 22 January 2020).

8. Mitchell, R.; Rose, P. "Learning If You Use It Increases": A Database of African Education Research to Inform Policy Practice. 2017. Available online: http://www.norrag.org/learning-use-increases-database-africaneducation-research-inform-policy-practice-rafael-mitchell-pauline-rose/ (accessed on 11 February 2020).

9. Dale, R. Globalization and education: Demonstrating a "common world educational culture" or locating a "globally structured educational agenda"? Educ. Theory 2000, 50, 427-448. [CrossRef]

10. Akkari, A. The new international agenda for education 2030: Soft consensus or a tool for mobilization of education's actors in the XXI century? Rev. Diálogo Educ. 2017, 17, 937-958.

11. World Commission on Environment and Development (WCED). Our Common Future; Oxford University Press: Oxford, UK, 1987.

12. Bell, D. Twenty-first Century Education: Transformative Education for Sustainability and Responsible Citizenship. J. Teach. Educ. Sustain. 2016, 1, 48-56. [CrossRef]

13. Joly, C. Sustainable Development: The possible utopia? Biota Neotrop. 2003, 3, 1-2. (In Portuguese) [CrossRef]

14. John, B.; Caniglia, G.; Bellina, L.; Lang, D.; Laubichler, M. The Glocal Curriculum: A practical guide to Teaching and Learning in an Interconnected World; Critical Aesthetics Publishing: Baden-Baden, Germany, 2017.

15. Chipindo, P. Environmental Education and Sustainable Development. Órbita 2019, 6, 51-62.

16. Silva Lopes, B.; Costa, N.; Matias, F.M. Impact evaluation of two master courses attended by teachers: An exploratory research in Angola. Probl. Educ. 21st Century 2016, 74, 49-60.

17. Costa, N.; Matias, B.F.; Lopes, B. Relatório final do Projeto "Avaliação do impacto dos cursos de mestrado Desenvolvimento Curricular e Ensino das Ciências" /Final Report of the project "Impact evaluation of the master courses Curricular Development and Science Teaching" (2012-2016); Editora: Aveiro, Portugal, 2018; ISBN 978-972-789-.

18. Costa, N.; Lopes, B.; Matias, F. Science Teacher Development in a Global world: A study centred in master dissertations in Angola. In Education and New Developments; Carmo, M., Ed.; inScience Press: Lisbon, Portugal, 2018; pp. 170-174. 
19. Ikupa, M.; Wilfried, A.; Berry, A.; Saab, N. Student-teachers' commitment to teaching and intentions to enter the teaching profession in Tanzania. S. Afr. J. Educ. 2019, 39, 1-15. [CrossRef]

20. Flores, M.A. Linking teaching and research in initial teacher education: Knowledge mobilisation and research informed practice. J. Educ. Teach. 2018, 44, 621-636. [CrossRef]

21. Bürgener, L.; Barth, M. Sustainability competencies in teacher education: Making teacher education count in everyday school practice. J. Clean. Prod. 2018, 174, 821-826. [CrossRef]

22. Wiek, A.; Withycombe, L.; Redman, C.L. Key competencies in sustainability: A reference framework for academic program development. Sustain. Sci. 2011, 6, 203-218. [CrossRef]

23. Cebrián, G.; Junyent, M. Competencies in Education for Sustainable Development: Exploring the Student Teachers' Views. Sustainability 2015, 7, 2768-2786. [CrossRef]

24. Bourn, D.; Hunt, F.; Bamber, P. A Review of Education for Sustainable Development and Global Citizenship Education in Teacher Education (Background Paper Prepared for the 2017/8 Global Education Monitoring Report). 2017. Available online: https://unesdoc.unesco.org/ark:/48223/pf0000259566 (accessed on 18 November 2019).

25. Wibowo, Y.; Sadikin, A. Biology in the 21st-Century: Transformation in biology science and education in supporting sustainable development goals. J. Pendidik. Biol. Indones. 2019, 5, 285-296. [CrossRef]

26. Afonso, M. Curriculum knowledge and experiences in Angola: Theoretical basis, results and perspectives for change. In Jango of Curriculum Knowledge and Experiences—Angola, Brazil, Mozambique and Portugal; Afonso, M., John, J.M.G., Eds.; INIDE-MED: Luanda, Angola, 2019; pp. 19-49. (In Portuguese)

27. INIDE MED. Curricular Review: Results from the National Inquiry about the Curricular Adequation-INACUA-in Angola-2018-2025; Mensagem Editora: Luanda, Angola, 2019. (In Portuguese)

28. Lunga, V. Strategy for Adopting Environmental Education and Health Promotion: Case Study at the 1st Cycle 1118 Secondary School “Kasseque I” of Benguela. 2015. Available online: https://bdigital.ufp.pt/bitstream/ 10284/4670/1/Toya\%20TESE\%20FINAL\%2006_01_2014.pdf (accessed on 3 March 2020). (In Portuguese).

29. Yin, R. The Case Study as a Serious Research Strategy. Knowl. Creat. Diffus. Util. 1981, 3, 97-114. [CrossRef]

30. Silva Lopes, B.; Pedrosa-de-Jesus, H.; Watts, M. The Old Questions Are the Best: Striving against Invalidity in Qualitative Research. In Theory and Method in Higher Education Research; Huisman, J., Tight, M., Eds.; Emerald Group Publishing: Bingley, UK, 2016; pp. 1-22.

31. Bardin, L. Content Analysis; Presses Universitaires: Paris, France, 2007. (In French)

32. Costa, N. ; At the Rooths of the Imbondeiro Tree: Dialogues with Education in African Contexts; UA Editora: Aveiro, Portugal, 2019. (In Portuguese)

33. Julião, A. Autonomia Curricular Autonomy of the teacher in Angola: Limits, challenges and possibilities. Rev. Contemp. De Educ. 2019, 14, 309-327. (In Portuguese)

34. Darling-Hammond, L. Research on Teaching and Teacher Education and Its Influences on Policy and Practice. Educ. Res. 2016, 45, 8-91.

(C) 2020 by the authors. Licensee MDPI, Basel, Switzerland. This article is an open access article distributed under the terms and conditions of the Creative Commons Attribution (CC BY) license (http://creativecommons.org/licenses/by/4.0/). 